\title{
Extended lactation in high-yielding dairy cows. Il. Effects on milk production, udder health, and body measurements
}

\author{
G. Niozas, ${ }^{1}$ G. Tsousis, ${ }^{2 *}$ C. Malesios, ${ }^{3}$ I. Steinhöfel, ${ }^{4}$ C. Boscos,${ }^{2}$ H. Bollwein,${ }^{5}$ and M. Kaske ${ }^{5}$ \\ ${ }^{1}$ Clinic for Cattle, University for Veterinary Medicine, 30173 Hannover, Germany \\ ${ }^{2}$ Clinic of Farm Animals, Aristotle University of Thessaloniki, 54627 Thessaloniki, Greece \\ ${ }^{3}$ Aston Business School, Aston University, B4 7ET Birmingham, United Kingdom \\ ${ }^{4}$ Saxon State Office for Environment, Agriculture and Geology (LfULG), 01311 Dresden, Germany \\ ${ }^{5}$ Department for Farm Animals, Vetsuisse Faculty, University of Zurich, 8057 Zurich, Switzerland
}

\section{ABSTRACT}

The objective of this prospective field study was to evaluate the effects of extending the lactation period of high-yielding dairy cows on milk production, udder health characteristics, and development of body condition. On $40 \mathrm{~d}$ in milk (DIM), an examination of the genital tract (transrectal palpation, sonography, vaginoscopy) was performed. Cows without signs of clinical endometritis were blocked by parity and were randomly allocated to 1 of 3 experimental groups with a voluntary waiting period of 40,120, and $180 \mathrm{~d}$, respectively (G40, n = 135; G120, n = 141; G180, n = 139). Mean daily milk and energy-corrected milk production did not differ between the 3 groups regarding the first 305 $\mathrm{d}$ or for the whole lactation (d 1 and up to dry off, culling, or $600 \mathrm{DIM}$ ). In late lactation (306 to $600 \mathrm{DIM})$, G40 had lower average productivity (23.8 kg) compared with G120 $(26.5 \mathrm{~kg})$, with G180 showing intermediate values $(25.7 \mathrm{~kg})$. The extended lactation groups showed greater persistency, as the rate of decline based on a Wilmink function was lower for G120 ( $c=-0.063$ and -0.045 for milk and energy-corrected milk, respectively) and G180 ( $c=-0.061$ and -0.047$)$ compared with G40 ( $c=-0.071$ and -0.056$)$. We found no difference between the 3 groups regarding the evaluated udder health characteristics (somatic cell count, incidence of mastitis, and days off milk due to mastitis). More cows in G180 (7.9\%) were culled due to low productivity compared with G40 (0.7\%) and as a tendency compared with G120 (2.8\%). Moreover, cows of G180 showed higher median body condition score at the time of dry off compared with cows of both G40 and G120 (3.50 for G180 vs. 3.25 for both G40 and G120). At the time of dry off, G180 cows also had greater backfat thickness $(25.0 \mathrm{~mm})$ compared with both G40 (22.2 $\mathrm{mm})$ and G120 cows $(21.6 \mathrm{~mm})$. Based on our results,

Received May 25, 2018.

Accepted September 11, 2018.

*Corresponding author: tsousis@vet.auth.gr the extension of the voluntary waiting period of highyielding cows up to $120 \mathrm{~d}$ has no adverse effects regarding milk production, involuntary culling, udder health, or BCS gain.

Key words: extended lactation, dairy cow, milk production, udder health, body condition

\section{INTRODUCTION}

Reproductive and milk production efficiency are the most important aspects for the financial viability of a modern dairy. An optimum calving interval of 12 to 13 mo has been suggested in various studies to maximize the number of peak lactations that a cow achieves during its productive life (Weller and Folman, 1990). Over the past decades, the average milk yield of dairy cows has increased as a result of improvements in the fields of genetics and nutrition. Cows are now capable of sustaining their production far more than the minimum recommended lactation length of $305 \mathrm{~d}$ (Österman and Bertilsson, 2003; Kolver et al., 2006; Auldist et al., 2007). However, for every 5 -kg increase in milk production at dry off, the risk of an IMI is elevated by $77 \%$ (Rajala-Schultz et al., 2005). Moreover, the period from the onset to the peak of lactation is associated with the highest prevalence of reproductive and productive diseases, and therefore with an increased risk of culling (Roemer, 2011). According to some researchers, the establishment of extended lactations offers an alternative way to overcome these problems (Knight, 2005).

The principal idea behind the deliberate delay of rebreeding is to overcome the detrimental effects of negative energy balance on fertility. In the accompanying study of our working group, a positive effect of extending the lactation on various fertility measures was found (Niozas et al., 2019). Moreover, the replacement of a shorter lactation with a more prolonged lactation would reduce the total number of parturitions and, consequently, the animal's exposure to the high-risk period of early puerperium (Knight, 2005). The implementation of extended lactations can be advantageous 
for low-cost pasture-based systems, as it addresses the problems of the seasonally concentrated calvings (Borman et al., 2004). Moreover, it can be used as an alternative management practice for cows that failed to conceive in the predetermined time interval (Butler et al., 2006). Even in intensive dairy systems, lactations with an extended length are not necessarily of lower productivity provided that animals sustain a high level of persistency (Arbel et al., 2001; Österman and Bertilsson, 2003). Previous studies have demonstrated that increased milking frequency (Österman and Bertilsson, 2003), the administration of recombinant bST (van Amburgh et al., 1997), or a high plane of nutrition (Kolver et al., 2007) can lead to higher daily milk production in extended compared with conventional lactation length. This effect was more apparent in primiparous than pluriparous cows due to their greater persistency (Arbel et al., 2001); however, it remains unclear if such management practices are sustainable under commercial farm conditions.

Nonetheless, the extension of the lactation is possible to have some major drawbacks. Cows with an extended calving interval spend more time in late lactation, which could lead to increased milk losses due to the elevated milk SCC associated with this stage of lactation (Hortet et al., 1999; Hagnestam-Nielsen et al., 2009). Another point of concern derives from the fact that the ability of cows to lactate beyond the conventional 305-d lactation varies among individual animals (Kolver et al., 2006, 2007; Auldist et al., 2007). Thus, a proportion of cows will experience low production levels and will be involuntary dried off remote from parturition. Apart from the direct financial implications of this situation, animals with an extended calving interval will spend more time in late lactation, during which a greater partitioning of nutrients moves away from the udder and toward body reserves (Delany et al., 2010; Marett et al., 2011, 2015). As such, these animals are in a greater risk of obesity, which in turn could have a negative effect on the following lactation (Roche et al., 2009).

The purpose of our study was to compare the productive performance of cows randomly assigned to 1 conventional and 2 extended lactation protocols by prolonging the voluntary waiting period up to 120 and 180 d. Moreover, the effect of these management practices on the udder health and the body development of dairy cows was evaluated.

\section{MATERIALS AND METHODS}

The study was carried out in a large dairy farm in Saxony, Germany (MVA Ruppendorf, Klingenberg ot Ruppendorf, Germany). Based on data from the year 2012 the farm had a total of 1,092 lactating Holstein-
Friesian cows and an average milk production of 11,488 $\mathrm{kg} / 305 \mathrm{~d}$ (4.09\% fat and $3.27 \%$ protein). Animals were housed indoors in a freestall barn with concrete slatted floor and cubicles with mattresses. Lactating cows were milked with an automatic milking system (AMS; Lely Astronaut A4, Maassluis, the Netherlands).

Details of the study herd and examination protocols are reported in a companion paper (Niozas et al., 2019). Briefly, all calvings for the period from January 1 to December 31, 2013, were monitored and recorded. Animals without severe dystocia and free from life-threatening puerperal diseases, including grade 3 metritis (Sheldon et al., 2006) and septicemic mastitis, were eligible for an examination of their reproductive tract at 40 DIM by transrectal palpation, vaginoscopy, and sonography (Tringa linear, Esaote/Pie Medical, Maastricht, the Netherlands) equipped with a $5-\mathrm{MHz}$ linear transducer. Animals with endometritis and animals with evident health disorders were excluded from the study, whereas the rest of the animals were blocked by parity and were randomly (based on the last digit of the ear tag) allocated to 1 of the 3 experimental groups with a voluntary waiting period (VWP) of 40 (G40; n = 135), 120 (G120; n = 141), or $180 \mathrm{~d}(\mathbf{G 1 8 0}$; $\mathrm{n}=139$ ). Sample size estimation was performed for main reproductive measures (Niozas et al., 2019). Cows were dried off $6 \mathrm{wk}$ before the expected calving date or when the average daily milk production was under 15 $\mathrm{kg} / \mathrm{d}$ for 5 consecutive days. Production diseases were diagnosed and treated by the veterinarian and the staff of the farm. Any cow with an average weekly milk production less than $15 \mathrm{~kg} / \mathrm{d}$ and found nonpregnant was culled due to low productivity $(\mathrm{n}=16)$.

\section{Milking Records and Udder Health Data}

The AMS provided individual daily milk records throughout the lactation as well as data concerning milk conductivity and temperature. All analyses in the present study were based on the actual daily recordings. Endpoint for the follow up of a cow was set at 600 DIM. The mean daily milk production was calculated as the sum of daily milk productions divided by the actual number of days that a cow was milked, and it was determined for the initial $100 \mathrm{~d}$ of the lactation, for the period between 101 and 200 DIM, between 201 and 305 DIM, for the initial $305 \mathrm{~d}$ of the lactation, for the period between 306 and 600 DIM, and for the whole lactation (d 1 and up to dry off, culling or 600 DIM) in each group. Animals with increased milk conductivity (>70 standardized units as measured by the AMS during milking) were examined by the personnel of the farm; those cows showing any macroscopic alterations in the milk (flakes, watery, clots or bloody), with or 
without mastitis associated clinical symptoms (e.g., oedematous and painful udder, elevated body temperature), were diagnosed with clinical mastitis (Schukken et al., 2011). However, a SCC evaluation of the milk from cows that were alerted by the AMS as animals with mastitis and not having the previously mentioned symptoms was not performed. These animals were housed, treated, and milked in a separate group until the end of the milk withdrawal time from the administered therapy, when they rejoined the lactating group. Daily milk records were not available for animals with mastitis during the time of therapy and are reported as days off milk due to mastitis. A cow was considered culled due to mastitis if the animal died due to severe septicemic mastitis or if it was tested positive for Streptococcus agalactiae or Staphylococcus aureus and was removed from the farm. Milk production, including the milk fat, protein, urea, and lactose concentration, as well as SCC were measured monthly by the State Control Association (Landeskontrollverband, Lichtenwalde, Germany). Energy-corrected milk (with $4.0 \%$ fat and $3.4 \%$ protein) for every cow and monthly measurement was calculated based on the equation (GfE, 2001):

$$
\begin{gathered}
\mathrm{ECM}(\mathrm{kg})=\text { milk }(\mathrm{kg}) \times(0.38 \times \text { fat } \% \\
+0.21 \times \text { protein } \%+1.05) / 3.28
\end{gathered}
$$

Based on the monthly milk production and ECM values, a scatter plot was derived for every cow separately to explore the relationship between milk yield and ECM. In the vast majority of cases, a linear relationship was evident. Thus, a linear regression equation between ECM and milk yield was obtained based on the available measurements. From the derived equations and for every cow separately, daily ECM was calculated based on the available daily milk yield. In cases where a cow had $<4$ measurements or the derived correlation coefficient from the analysis indicated a weak correlation $(\mathrm{r}<0.50)$, no equation was derived. Thus, 19 out of 415 cows $(4.6 \%)$ were excluded from this analysis. In 370 out of the remaining 395 cows (93.7\%), a strong correlation between ECM and milk yield was evident $(\mathrm{r} \geq 0.7)$. Mean daily ECM was calculated for the same periods as described above for mean daily milk production. To compare the development of SCC between the 3 groups across time, the lactation was divided into $30-\mathrm{d}$ periods and every measurement was assigned to the corresponding period that the measurement took place.

\section{BCS and Backfat Thickness}

To assess the changes in the body condition of the animals throughout the lactation, both BCS and back- fat thickness (BFT) were estimated. A 5-point method with increments of 0.25 (Edmonson et al., 1989) was used to estimate the BCS of the animals. The BFT was measured with the method described by Schröder and Staufenbiel (2006). An ultrasound device (Tringa linear, Esaote/Pie Medical) equipped with a $5-\mathrm{MHz}$ linear transducer was used to measure BFT. Briefly, after the preparation of the skin with a solution of $70 \%$ alcohol, the transducer was placed vertically on the imaginary line connecting the tuber coxae and the tuber ischia and approximately $10 \mathrm{~cm}$ cranial to tuber ischia. The picture gained from the measurement was frozen and the thickness of subcutaneous fat was measured at site as the distance (in millimeters) between skin and the fascia trunci profunda. The measurement of BFT always included the thickness of the skin. To avoid bias, BCS was always estimated first. Both measurements were performed at the day of calving, at $15,30,45,60$, 90, 120, and 180 DIM, and every 2 mo thereafter until the end of the lactation period. An additional measurement was performed at dry off.

\section{Statistical Analysis}

Statistical analyses were conducted using SAS version 9.3 (SAS Institute Inc., Cary, NC), unless otherwise stated. To compare the 3 groups, G40, G120, and G180, with respect to BCS development, univariate analysis using the Kruskal-Wallis and Wilcoxon's 2-sample test (PROC NPAR1WAY) for every time point was performed due to the underlying distribution of the data. The same analysis was used to compare primi- with pluriparous cows regarding BCS development. Variables with repeated measures (BFT, ECM, and SCC) were analyzed with the use of repeated measures with the mixed procedure of SAS. The models included group, parity, day or period of measurement, and their interactions as fixed effects and included cow as a random effect. The season was included in the analyzed models as a binary variable, with the months from May to October defined as summer months and those between November and April as winter months. However, season had no effect whatsoever in this or any of the following analyses; thus, it was excluded and will be no further discussed. Covariance structure was chosen based on the values of the Akaike information criterion. Five models were run with different structures (compound symmetry, unstructured, firstorder autoregressive, first-order antedependence, and Toeplitz) and the model with the least Akaike information criterion was chosen. Backfat thickness data were square root transformed and SCC data were analyzed using the natural logarithm of SCC. Regarding mean daily milk yield and mean daily ECM, a mixed model 
that included group, parity, and their 2-way interaction was applied. Binary variables (\% cows culled, dried-off, and so on) were analyzed with the use of general linear mixed models (PROC GLIMMIX) that included group, parity, and their 2-way interaction. In all cases, pairwise comparisons were performed with the PDIFF command incorporating the Tukey adjustment. The rate of cows being dried off was additionally evaluated using the Kaplan-Meyer survival curves (PROC LIFETEST).

To provide estimates about the characteristics of the lactation curves, we applied a Bayesian modeling approach to test day records of milk and ECM based on the assumption of Wilmink's lactation function (Wilmink, 1987). For our analysis, data were truncated at 75th percentile of dry off DIM, as from this point on lactation curves were not smooth due to the few remaining animals in milk. As a result, lactation curves were estimated up to d 365 for G40, d 416 for G120, and d 469 for G180. The Wilmink equation is

$$
y=f(t)=\alpha+b \cdot \exp (-k \cdot t)+c \cdot t .
$$

The model proposed by Wilmink (1987) is a modification of the Cobby and Le Du model, and $k$ is related to the moment peak, which is about $50 \mathrm{~d}$ (Vargas et al., 2000). For the purposes of our study, $k$ was assumed equal to 0.065 (Silvestre et al., 2006). The scaling factor $\alpha$ represents yield at the beginning of lactation, $b$ is the inclining slope parameter up to peak yield, and $c$ is the declining slope parameter (Silvestre et al., 2006). The dependent variable $y=f(t)$ represents the milk production $(\mathrm{kg} /$ day) at time $t$ of the lactation period (in days).

We assumed a linear mixed effects structure to incorporate covariate information comprising the group and parity fixed effects, which we assumed would improve the accuracy of the estimates of Wilmink's lactation curve parameters. The fitted Bayesian model is described by the equations

$$
\begin{gathered}
y_{i j}=f\left(\theta_{i}, t_{i j}\right)+e_{i j}, \\
f\left(\theta_{i}, t_{i j}\right)=\alpha_{i}+b_{i} \exp \left(-k \cdot t_{i j}\right)+c_{i} t_{i j} \text {, and } \\
\boldsymbol{\theta}=\mathbf{X} \boldsymbol{\beta}+\mathbf{e},
\end{gathered}
$$

where $y_{i j}$ denotes the test-day record of the $i$ th cow at time $j(i=1,2, \ldots, \mathrm{n} ; j=1,2, \ldots, \mathrm{m}) ; \boldsymbol{\theta}$ is the vector comprising parameters of the Wilmink's function, that is $\boldsymbol{\theta}=\left(\alpha_{1}, \alpha_{2}, \ldots, \alpha_{n}, b_{1}, b_{2}, \ldots, b_{n}, c_{1}, c_{2}, \ldots\right.$, $\left.c_{n}\right)^{t}$; X denotes the data; and $\boldsymbol{\beta}$ denotes the vector of fixed effects. More specifically, we included as covariate information for explaining variation in the lactation curves of the animals included in our analysis, animal random effects as well as the fixed effect of group and parity. Hence, we have

$$
\begin{aligned}
& \alpha_{i}=\operatorname{beta} 0 . \alpha_{i}+\operatorname{beta1} . \alpha_{i} \times \operatorname{Group}_{i}
\end{aligned}
$$

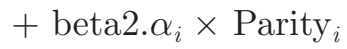

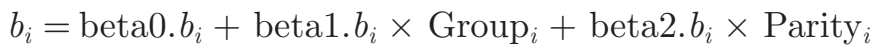

$$
\begin{aligned}
& c_{i}=\text { beta0. } c_{i}+\text { beta1. } c_{i} \times \operatorname{Group}_{i}
\end{aligned}
$$

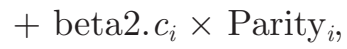

where beta0. $\theta_{i}(i=1,2, \ldots, 395)$ denote the coefficients for the animal random genetic effects for parameters $\alpha$, $b$, and $c$, beta1. $\theta$ denote the fixed effects parameters for the group effect on $\alpha, b$, and $c$, and beta2. $\theta$ denote the parameters of parity.

Our model assumes a unique curve to each cow, with all curves being exchangeable (i.e., similar in that they are sampled from a distribution of curves depending on the assumption for the densities of the $\alpha_{i}, b_{i}$, and $\left.c_{i}\right)$. This approach is considered to be most suitable in comparison to fitting a single curve across all cows or assuming complete independence among cows.

Finally, prior distributions for $\theta$ (i.e., parameters $\alpha$, $b$, and $c$ ) and residual variance were specified. Specifically, we placed vague priors for the model parameters, assuming that parameters of the model follow the wellknown Gaussian distribution, with zero mean and very large variance (restricting the prior though to be on the nonnegative domain for $\alpha$ parameter). Residuals are assumed to follow a Gaussian distribution with zero mean and constant variance, $\sigma_{e}^{2}$; that is, $e_{i} \sim N\left(0, \sigma_{e}^{2}\right)$. Posterior distributions for all model parameters then are obtained by the use of Markov chain Monte Carlo methods.

We used WinBUGS (Spiegelhalter et al., 2004) to implement the Bayesian approach. All Markov chain Monte Carlo models were implemented using Gibbs sampler, considering a burn-in period of 5,000 iterations, and then monitoring a large chain of 100,000 iterations, where 1 in 10 samples was kept so the marginal density estimations from each of the parameters was based on a sample of 10,000. The source code of the fitted models is available upon request from the corresponding author.

For the purposes of the current analysis, peak yield (PY) was calculated utilizing the parameter estimates from the fit of the Wilmink models for milk and ECM, respectively, as the maximum test day milk yield. Peak time (PT) is the test time at which daily milk yield reaches maximum. Peak time values of the fitted 
Table 1. Milk production variables for cows with a 40-, 120-, and 180-d voluntary waiting period (VWP) length (G40, G120, and G180, respectively) based on a mixed model with VWP length, parity, and their 2-way interaction as fixed variables (LSM \pm SEM)

\begin{tabular}{|c|c|c|c|c|c|c|c|c|c|c|}
\hline Variable $^{1}$ & \multicolumn{3}{|c|}{ Group } & SEM & \multicolumn{2}{|c|}{ Parity } & SEM & \multicolumn{3}{|c|}{$P$-value } \\
\hline Mean daily ECM 1-100 DIM (kg/d) & 38.4 & 39.0 & 39.6 & 0.4 & $33.9^{\mathrm{a}}$ & $44.1^{\mathrm{b}}$ & 0.3 & 0.16 & $<0.0001$ & 0.02 \\
\hline Mean daily milk $101-200$ DIM (kg/d) & 39.0 & 39.4 & 39.7 & 0.5 & $36.5^{\mathrm{a}}$ & $42.3^{\mathrm{b}}$ & 0.5 & 0.71 & $<0.0001$ & 0.16 \\
\hline Mean daily ECM 101-200 DIM (kg/d) & 37.0 & 37.5 & 38.1 & 0.5 & $34.8^{\mathrm{a}}$ & $40.3^{\mathrm{b}}$ & 0.4 & 0.18 & $<0.0001$ & 0.11 \\
\hline Mean daily milk 1-305 DIM (kg/d) & 37.4 & 38.1 & 38.2 & 0.5 & $34.7^{\mathrm{a}}$ & $41.0^{\mathrm{b}}$ & 0.4 & 0.48 & $<0.0001$ & 0.11 \\
\hline Mean daily ECM 1-305 DIM (kg/d) & 35.8 & 36.5 & 36.9 & 0.4 & $33.6^{\mathrm{a}}$ & $39.3^{\mathrm{b}}$ & 0.3 & 0.15 & $<0.0001$ & 0.10 \\
\hline Mean daily milk 306-600 DIM (kg/d) & $23.8^{\mathrm{a}}$ & $26.5^{\mathrm{b}}$ & $25.7^{\mathrm{ab}}$ & 0.6 & $27.0^{\mathrm{a}}$ & $23.6^{\mathrm{b}}$ & 0.5 & 0.007 & $<0.0001$ & 0.36 \\
\hline Mean daily ECM 306-600 DIM (kg/d) & $26.2^{\mathrm{a}}$ & $28.3^{\mathrm{b}}$ & $27.8^{\mathrm{ab}}$ & 0.5 & $28.4^{\mathrm{a}}$ & $26.5^{\mathrm{b}}$ & 0.5 & 0.03 & 0.003 & 0.92 \\
\hline Mean daily milk $1-600$ DIM $(\mathrm{kg} / \mathrm{d})$ & 36.1 & 35.8 & 34.9 & 0.5 & $33.3^{\mathrm{a}}$ & $37.8^{\mathrm{b}}$ & 0.4 & 0.15 & $<0.0001$ & 0.17 \\
\hline Mean daily ECM 1-600 DIM (kg/d) & 34.9 & 34.8 & 34.5 & 0.4 & $32.6^{\mathrm{a}}$ & $37.0^{\mathrm{b}}$ & 0.3 & 0.70 & $<0.0001$ & 0.18 \\
\hline
\end{tabular}

${ }^{\mathrm{a}-\mathrm{c}}$ Values within group or parity, within a row with different superscripts differ $(P<0.05)$.

${ }^{1} \mathrm{ECM}$ based on the equation [milk $(\mathrm{kg}) \times(0.38 \times$ fat $\%+0.21 \times$ protein $\left.\%+1.05) / 3.28\right]$.

${ }^{2} \mathrm{G} \times \mathrm{P}=$ group by parity interaction.

models were calculated by equalizing the first partial derivations of the Wilmink function to zero; that is,

$$
\mathrm{PT}=-\frac{1}{k} \cdot \ln \left(\frac{c}{k b}\right) .
$$

Accordingly, PY values were estimated by replacing calculated PT values in the Wilmink function. Results are expressed as least squares means \pm standard error of the mean, unless otherwise stated. Level of significance was set at $P<0.05$.

\section{RESULTS}

\section{Milk Production}

The results regarding mean daily milk and ECM production at specific periods are presented on Table 1. The 3 groups did not differ $(P>0.05)$ to their mean daily milk production (neither actual nor ECM) of the first 100 or from 101 to $200 \mathrm{~d}$. An interaction between group and parity was evident regarding average daily milk and ECM production during the first $100 \mathrm{~d}$, as pluriparous cows of G180 produced more than those of G120 (48.2 and 45.4 vs. 45.5 and 43.1 for milk and ECM of G180 vs. G120, respectively; both $P<0.05$ ). Cows in G120 and, as a tendency, G180 showed higher mean daily production than G40 from d 201 to 305 and from d 306 onwards (Table 1). However, mean daily milk and ECM production did not differ between the 3 groups regarding the first $305 \mathrm{~d}$ or for the whole lactation (d 1 and up to dry off, culling, or 600 DIM; Table 1). No difference regarding milk production was evident between G120 and G180 in any variable. Pluriparous cows had higher mean milk and ECM production re- garding early (d 1-100), mid (d 101-200), the first 305 $\mathrm{d}$, and the whole lactation compared with primiparous cows (all $P<0.0001$ ). However, primiparous cows had better mean daily milk production (both actual and ECM) compared with pluriparous from d 306 onwards.

Summary statistics (medians and the corresponding 95\% credible intervals) of the main parameters of the Wilmink models for milk and ECM are presented in Tables 2 and 3 and in Figures 1 and 2, respectively. Along with the results based on the complete data, we present results for the various levels of groups and parity separately. The results are typical of a standard lactation curve, where $b<0$ and $c<0$. Regarding the lactation curves derived from daily milk recordings, the yield at the beginning of lactation was marginally higher for G180 compared with G40 and G120, leading to a greater overall PY (46.86 for G180 vs. 45.78 and 45.61 for G40 and G120, respectively) by almost identical rates of incline (Table 2). Peak time ranged from 51.53 (G40) to 53.18 (G120) DIM. The rate of decline was higher (lower $c$ values indicate higher rate of decline) for G40 ( $c=-0.071)$ compared with G120 and G180 ( $c$ $=-0.063$ and -0.061 , respectively; Table 2 and Figure $1 \mathrm{~A})$. Based on the derived lactation curves, mean daily milk production up to d 365 for G40 was $36.3 \mathrm{~kg} / \mathrm{d}$, up to d 419 for G120 was $35.6 \mathrm{~kg} / \mathrm{d}$, and up to d 446 for G180 was $35.8 \mathrm{~kg} / \mathrm{d}$. First-parity cows had much lower yield at the beginning of lactation and lower rate of incline, lower PY, later PT, and much lower rate of decline compared with pluriparous cows (Table 2 and Figure 1B).

Regarding the lactation curves derived from daily ECM recordings, the same pattern as for milk was noted; specifically, G180 showed marginally higher 
Table 2. Median parameter estimates ( $\alpha, b$, and $c$ with $95 \%$ credible intervals), peak time (PT), and peak yield (PY) estimated values of the lactation curve based on daily milk recordings

\begin{tabular}{|c|c|c|c|c|c|}
\hline Random effects model ${ }^{1}$ & $\alpha$ & $b$ & $c$ & $\mathrm{PT}$ & PY \\
\hline G40 & $50.53(49.73,51.28)$ & $-31.12(-33.88,-28.35)$ & $-0.071(-0.075,-0.067)$ & 51.53 & 45.78 \\
\hline Parity 1 & $41.31(40.94,41.66)$ & $-28.8(-30.23,-27.36)$ & $-0.032(-0.033,-0.030)$ & 62.60 & 38.81 \\
\hline Parity $\geq 2$ & $55.66(55.09,56.2)$ & $-30.58(-32.7,-28.42)$ & $-0.082(-0.084,-0.080)$ & 49.05 & 50.38 \\
\hline
\end{tabular}

${ }^{1}$ Voluntary waiting periods of 40 (G40), 120 (G120), and 180 (G180) days.

PY compared with G40 and G120 (43.05 vs. 42.25 vs. 41.85 , respectively). Moreover, the rate of decline was higher for G40 ( $c=-0.056)$ compared with G120 and G180 ( $c=-0.045$ and -0.047 , respectively; Table 3 and Figure 2A). Based on the derived lactation curves, mean daily ECM production up to d 365 for G40 was $34.8 \mathrm{~kg} / \mathrm{d}$, up to d 419 for $\mathrm{G} 120$ was $34.7 \mathrm{~kg} / \mathrm{d}$, and up to d 446 for G180 was $34.5 \mathrm{~kg} / \mathrm{d}$. Regarding the effect of parity on the lactation curves derived from ECM recordings, exactly the same pattern as described above was noticed (Table 3 and Figure 2B).

\section{SCC and Udder Health}

We found no difference between the 3 groups regarding the number of the SCC up to d $330(P=0.63$; Figure 3$)$. Up to this time point, there was a time effect $(P<0.0001)$, as we noted a gradual increase of SCC with increasing DIM. Moreover, a significant interaction between group and time was apparent $(P$ $=0.006$ ), because G40 had numerically lower SCC up to d 120 and numerically higher SCC from that point on compared with the other 2 groups (Figure 3 ). No difference between the 3 groups was significant at any specific day. From d 330 to 420, we found no difference between G120 and G180 ( $P=0.71)$ or a group by time interaction; however, a weak time effect $(P=0.06)$ was evident. Primiparous cows had lower SCC values $(3.9$ $\pm 0.06)$ compared with pluriparous cows $(4.6 \pm 0.05$, $P<0.0001)$ throughout the experimental period, with the exception of the first postpartum measurement (4.3 \pm 0.1 vs. $4.0 \pm 0.1$, respectively, $P=0.04)$. No group by parity interaction was significant at any specific day.
We observed no difference between the 3 groups regarding the incidence of mastitis within the first 320 d of lactation nor throughout the study period (Table 4). There was also no difference between the 3 groups regarding the average number of mastitis cases per infected cow or the average days off milk due to mastitis within $305 \mathrm{~d}$ or throughout the study. We noted no difference between the 3 groups regarding the proportion of cows culled within the first $305 \mathrm{~d}$ of lactation, either overall or due to mastitis. However, a greater number of cows in G180 were culled compared with G40 (20.9 vs. $11.1 \%$, respectively; $P=0.05$ ). Additionally, more cows in G180 (7.9\%) were culled due to low productivity compared with $\mathrm{G} 40(0.7 \% ; P=0.01)$ and as a tendency compared with G120 $(2.8 \% ; P=0.07)$. Pluriparous cows had worse udder health compared with primiparous in all variables, except from the average number of days off milk due to mastitis (Table 4).

\section{Dry Off Management}

Variables regarding dry off management are shown in Table 5 and Figure 4. The actual days that the cows were dried off were 341, 396, and 447 for G40, G120, and G180, respectively (all $P<0.0001$ ). Additionally, an interaction between group and parity was apparent, as G40 pluriparous cows were dried off later than primiparous (351 vs. 330 d); in G120 both groups were almost simultaneously dried (393 vs. 399 d, respectively), and in G180 pluriparous were dried off earlier than primiparous (436 vs. 438 d). Dry period length was greater in G180 (57.9 $\pm 2.3 \mathrm{~d})$ compared with G40 (48.4 \pm 2.2 d). Cows of G180 had lower milk

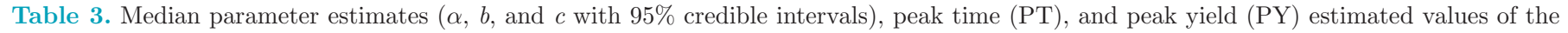
lactation curve based on daily ECM recordings

\begin{tabular}{|c|c|c|c|c|c|}
\hline Random effects model $^{1}$ & $\alpha$ & $b$ & $c$ & $\mathrm{PT}$ & PY \\
\hline Complete data & $45.28(45.19,45.36)$ & $-20.17(-20.5,-19.84)$ & $-0.046(-0.047,-0.045)$ & 51.54 & 42.20 \\
\hline G40 & $45.92(45.75,46.08)$ & $-22.46(-23.04,-21.87)$ & $-0.056(-0.057,-0.055)$ & 50.17 & 42.25 \\
\hline G120 & $44.89(44.74,45.04)$ & $-20.69(-21.28,-20.09)$ & $-0.045(-0.046,-0.044)$ & 52.27 & 41.85 \\
\hline G180 & $46.16(46.02,46.3)$ & $-19.62(-20.18,-19.06)$ & $-0.047(-0.048,-0.045)$ & 50.78 & 43.05 \\
\hline Parity 1 & $38(37.89,38.1)$ & $-19.59(-20,-19.17)$ & $-0.023(-0.024,-0.022)$ & 61.75 & 36.23 \\
\hline Parity $\geq 2$ & $49.89(49.79,50)$ & $-21.08(-21.48,-20.67)$ & $-0.062(-0.063,-0.061)$ & 47.62 & 45.98 \\
\hline
\end{tabular}

${ }^{1}$ Voluntary waiting periods of 40 (G40), 120 (G120), and 180 (G180) days. 


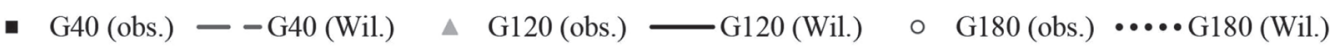
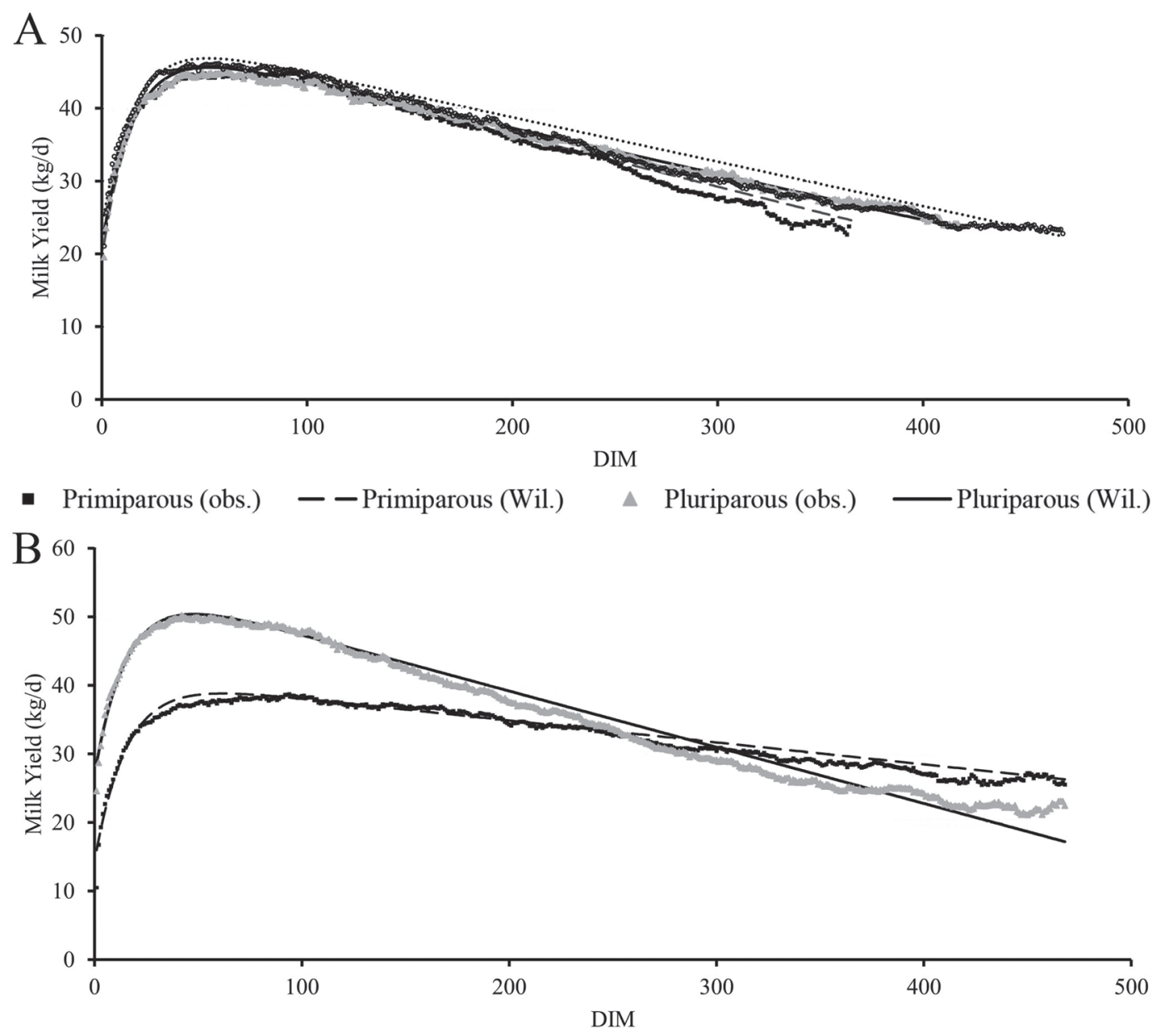

Figure 1. (A) Observed (obs.) and estimated with Wilmink function (Wil.) development of milk yield in cows with a 40-, 120-, and 180-d voluntary waiting period (VWP) length (G40, G120, and G180, respectively) and (B) in primi- and pluriparous cows.

production at the day of dry off and at the week before dry off (16.9 and $17.9 \pm 0.6)$ compared with both G40 (19.1 and $19.9 \pm 0.5 ; P=0.02$ and 0.03 , respectively) and G120 (19.1 and $20.0 \pm 0.5$; both $P=0.02$, respectively). Moreover, more cows in G180 were dried off with a weekly milk yield lower than $15 \mathrm{~kg} / \mathrm{d}(53.6 \%)$ compared with G40 and G120 (34.2 and 37.6\%; $P=$ 0.03 and 0.04 , respectively). Pluriparous cows had longer dry period, lower milk production at the day of and at the week before dry off, and a greater proportion were dried off with weekly milk yield below $15 \mathrm{~kg} / \mathrm{d}$ compared with primiparous cows.

\section{$B C S$ and BFT}

The BCS did not differ between the 3 groups from the day of the parturition and up to 240 DIM, whereas we noted a tendency $(P=0.07)$ for the groups to dif- fer at d 45 and 300, with the animals of group G120 having 0.25 median BCS lower than the other 2 groups (Figure 5A). At d 360, cows of the G120 were 0.25 median BCS thinner than the cows of the G180 ( $P$ $=0.03$ ). Moreover, cows of G180 showed higher median BCS at the time of dry off compared with cows of both G40 and G120 (3.50 \pm 0.50 for G180 vs. 3.25 \pm 0.50 for both G40 and G120; $P=0.03$ and 0.004, respectively). A greater proportion of cows of G180 compared with those of G40 and G120 had BCS at dry off higher than 3.5 (35.9 vs. 21.6 and 19.6\%; $P=$ 0.02 and 0.008 , respectively). Pluriparous cows showed greater BCS on d 0 and from d 360 onwards $(P<0.05)$ compared with primiparous, whereas primiparous cows had greater BCS from d 30 to $240(P<0.05)$. On d 15 and 300, we found no difference regarding BCS between primi- and pluriparous cows. Almost the same results were obtained regarding BFT measurements. Specifi- 


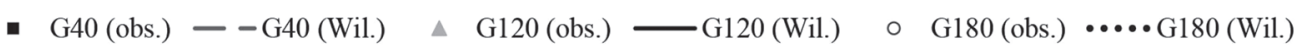

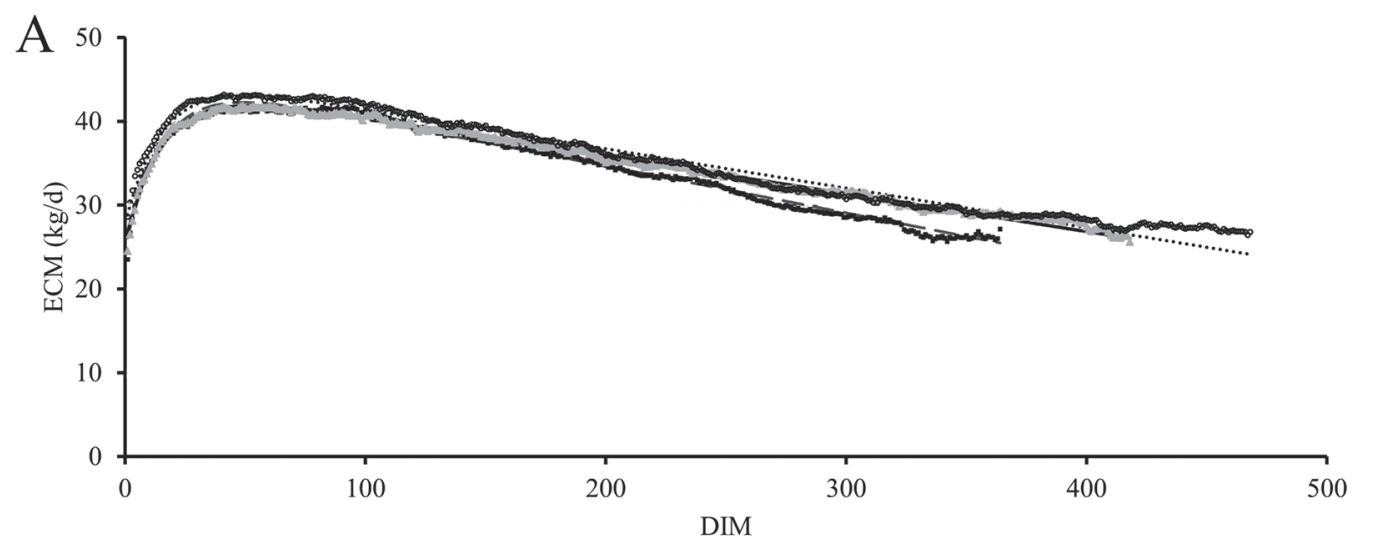

- Primiparous (obs.) - - Primiparous (Wil.) $\quad$ Pluriparous (obs.) — Pluriparous (Wil.)

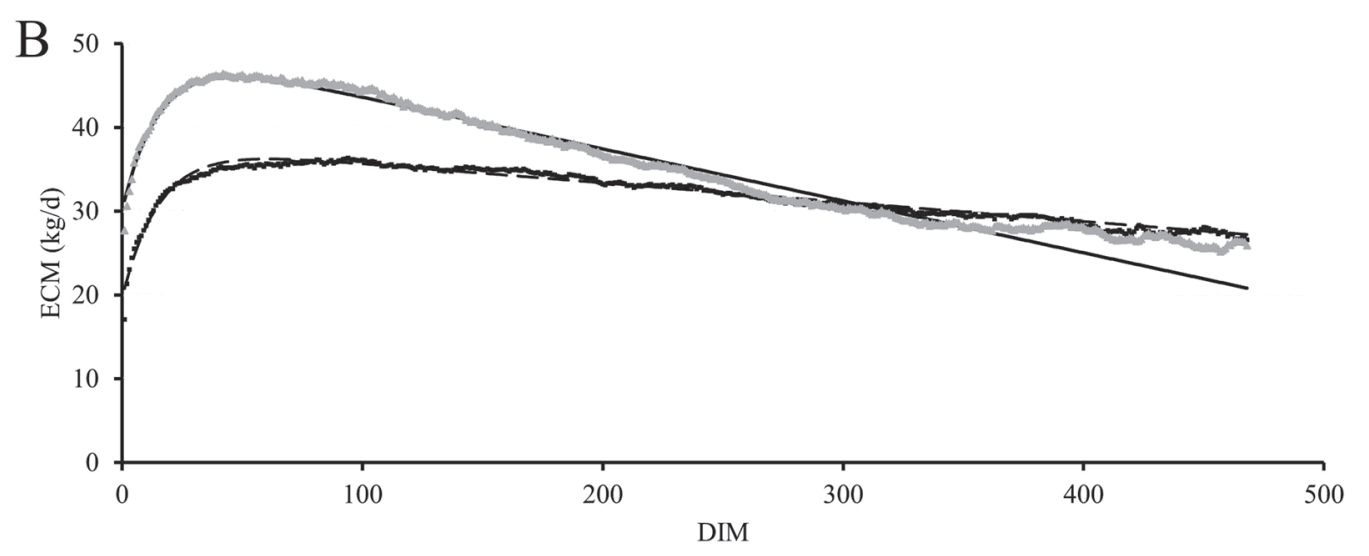

Figure 2. (A) Observed (obs.) and estimated with Wilmink function (Wil.) development of ECM in cows with a 40-, 120-, and 180-d voluntary waiting period (VWP) length (G40, G120, and G180, respectively) and (B) in primi- and pluriparous cows.

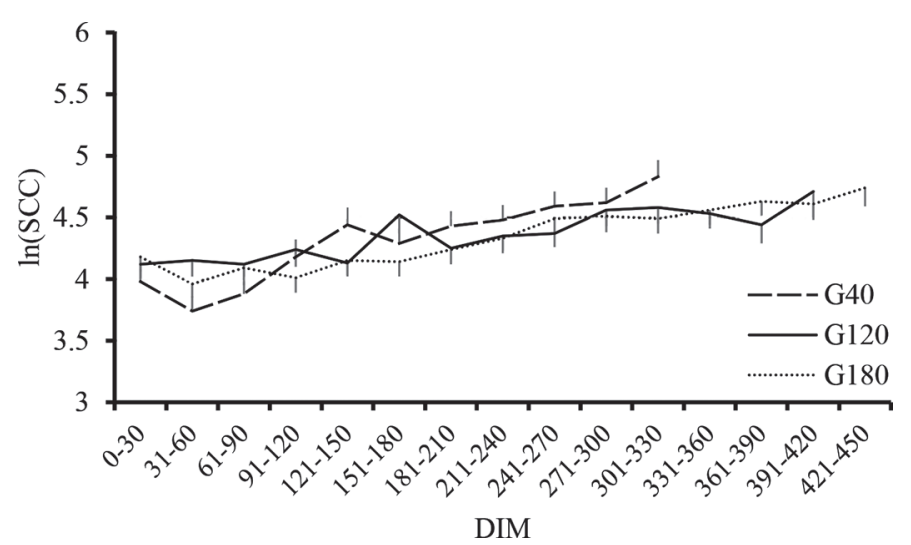

Figure 3. Development of SCC (expressed as the natural logarithm of SCC) in cows with a 40-, 120-, and 180-d voluntary waiting period (VWP) length (G40, G120, and G180, respectively) based on a mixed model for repeated measures with VWP length, period of measurement, and their interaction as fixed effects $(\mathrm{LSM} \pm \mathrm{SEM})$. cally, we noted a weak group effect up to d $300(P=$ 0.07), with G40 showing overall higher BFT than G120 $(P=0.05)$. No interaction between group and time was evident $(P=0.18$, Figure 5B). At d 360, G180 cows showed greater BFT (22.8 \pm 0.7$)$ compared with G120 cows $(21.0 \pm 0.7 ; P=0.04)$. At the time of dry off, G180 cows had greater BFT (25.0 \pm 0.7$)$ compared with both G40 (22.2 $\pm 0.7, P=0.01)$ and $\mathrm{G} 120$ cows $(21.6 \pm 0.7 ; P=0.002)$. Parity had no overall effect on the development of BFT $(P=0.75)$; however, we noted a significant interaction between parity and time $(P<$ 0.0001), as pluriparous cows had higher BFT values at partum compared with primiparous cows $(25.0 \pm 0.4$ vs. $21.7 \pm 0.5 ; P=0.0004$ ) followed by a higher BFT loss during the lactation (BFT at $120 \mathrm{~d} 11.1 \pm 0.4$ vs. $13.2 \pm 0.5$ for pluri- and primiparous, respectively; $P$ $=0.04)$. At dry off, pluriparous cows reached again greater BFT $(24.5 \pm 0.5)$ compared with primiparous cows $(20.3 \pm 0.5 ; P<0.0001)$. 


\section{Milk Production}

Based on the results of the present study, animals with an extended VWP produced on average only numerically, but not statistically, less kilograms of milk per DIM than animals bred in the early period. Animals from G180 reached their dry period with significantly lower milk production than cows from the other 2 groups. As shown in previous studies, the metabolic profile of animals (i.e., high plasma glucose, leptin, and IGF-I factor and low GH concentration) during the extended part of lactation is consistent with the reduction in milk production and the partitioning of the nutrients toward body reserves (Delany et al., 2010; Marett et al., 2011, 2017). In the same studies, however, great variability was present in the ability of animals to sustain an extended lactation, and the most persistent cows adapted their somatotropic axis in favor of lactation (i.e., increased growth hormone and, in some cases, decreased IGF-I plasma concentrations in comparison to less-persistent cows). This was evident in our study as well, as the rate of decline of the lactation curves of the extended groups was lower compared with G40. This finding is indicative of greater persistency in cows with extended VWP. In accordance to our results, Arbel et al. (2001) found that cows with an intentional delayed breeding after calving produced less milk per DIM than cows with a shorter VWP, with the difference being more obvious in pluriparous than primiparous cows. However, in the same study, when lactation was expressed as production of ECM per day of calving interval, animals with an extended lactation produced numerically (pluriparous) or significantly (primiparous) more ECM per day of calving interval than those with shorter lactations (Arbel et al., 2001). This difference could be attributed to the fact that cows with extended lactations have a larger proportion of milking days per days of dry period than cows with a shorter lactation. According to Arbel et al. (2001), primiparous cows profited the most from the extension of the lactation, which reflects the increased persistency of the primiparous compared with pluriparous cows, which was also noted in our study. Similar observations were made in the study of Österman and Bertilsson (2003), who found no difference in the production of ECM per day of calving interval between cows managed for a 12- and 18-mo calving interval, irrespective of the milking frequency used in their experiment. Our results also indicated no difference in the average daily ECM production between the 3 groups, as the increase in milk solids during the extended phase of the lactation counteracted the decline in mean daily milk produc- 
Table 5. Variables regarding dry-off management for cows with a 40-, 120-, and 180-d voluntary waiting period (VWP) length (G40, G120, and G180, respectively) based on a mixed model with VWP length, parity, and their 2-way interaction as fixed variables (LSM \pm SEM)

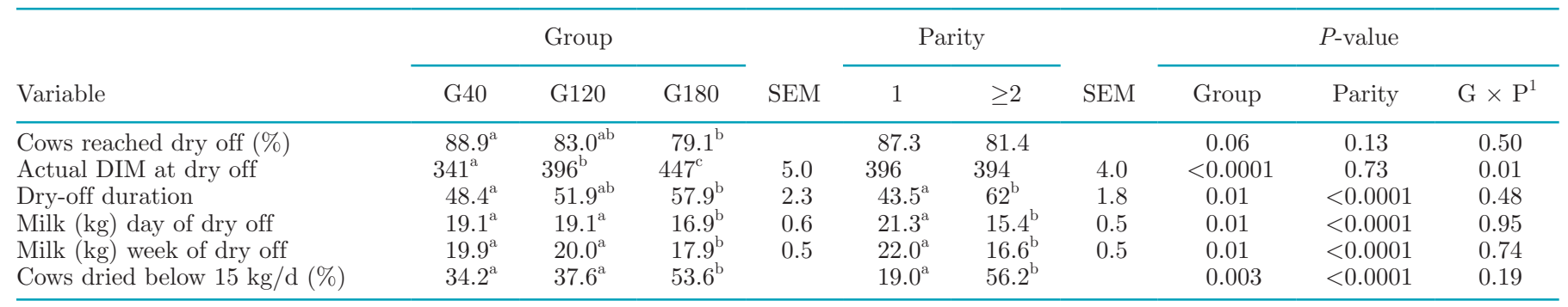

${ }^{a-c}$ Values within group or parity, within a row with different superscripts differ $(P<0.05)$.

${ }^{1} \mathrm{G} \times \mathrm{P}=$ group by parity interaction.

tion. Moreover, in accordance to the aforementioned studies, primiparous cows had greater persistency in our study, as total and daily milk and ECM production were higher in primiparous compared with pluriparous cows in the extended (over 305 DIM) lactation period. This finding was also directly evident from the derived lactation curves with the Wilmink function. As shown in previous studies, animals undergoing extended lactation have greater average milk solids production than animals with a standard 305-d lactation period (Österman and Bertilsson, 2003; Kolver et al., 2007; Sorensen et al., 2008). Moreover, the increased protein concentration in milk derived from animals managed for an extended lactation results in superior cheese yield production per $100 \mathrm{~kg}$ of milk in comparison to milk from animals with a typical 10-mo lactation (Auldist et al., 2010). For those reasons, the deliberate extension of the lactation period can be a beneficial management system, particularly for dairy farms that supply the cheese industry (Auldist et al., 2010; Maciel et al., 2016), dairy systems where payment is based on milk solids concentration (van Amburgh et al., 1997; Borman et al., 2004; Auldist et al., 2007), or if a reduction in milk solids results in payment penalties. The

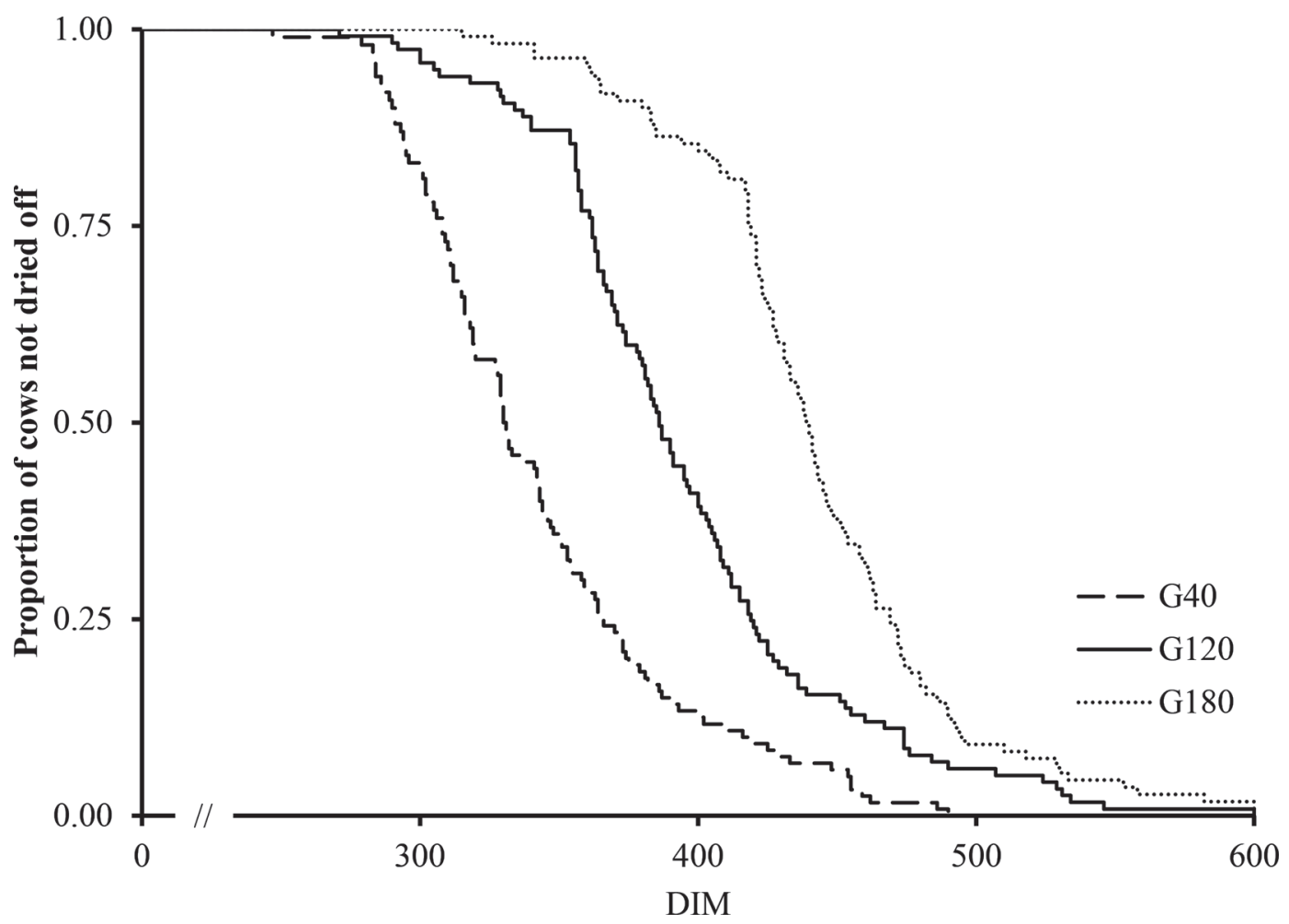

Figure 4. Kaplan-Meier survival curves for the proportion of cows not dried off in the 3 lactation groups. Median days to dry-off were 331 $\mathrm{d}$ for 40- (G40; 95\% confidence interval $=320-343), 386 \mathrm{~d}$ for $120-(\mathrm{G} 120 ; 95 \% \mathrm{CI}=379-397)$, and $440 \mathrm{~d}$ for 180-d voluntary waiting period $(\mathrm{G} 180 ; 95 \% \mathrm{CI}=431-446)$. 
greater persistency in the extended lactation groups could reflect the negative effect of pregnancy on lactation (Penasa et al., 2016).

\section{Udder Health}

In our study, the extension of the VWP did not have a negative effect on udder's health, as it did not lead to an increase in SCC or in the number of mastitis cases. These results are in accordance with studies that showed animals undergoing extended lactations with a preplanned 18-mo calving intervals had no significant increase in SCC (Österman et al., 2005; Sorensen et al., 2008). Moreover, in our results pluriparous cows had greater SCC than primiparous cows throughout the lactation, which agrees with observations from Sharma et al. (2013), who found a negative effect of age and parity on udder health. The increased SCC in our study could be partly explained by the increased mastitis incidence (as defined in our study) in pluriparous cows compared with primiparous cows, as the parity and stage of lactation have no effect on SCC in bacteriologically negative animals (Laevens et al., 1997). Considering the relative low sensitivity and specificity of the mastitis-detection
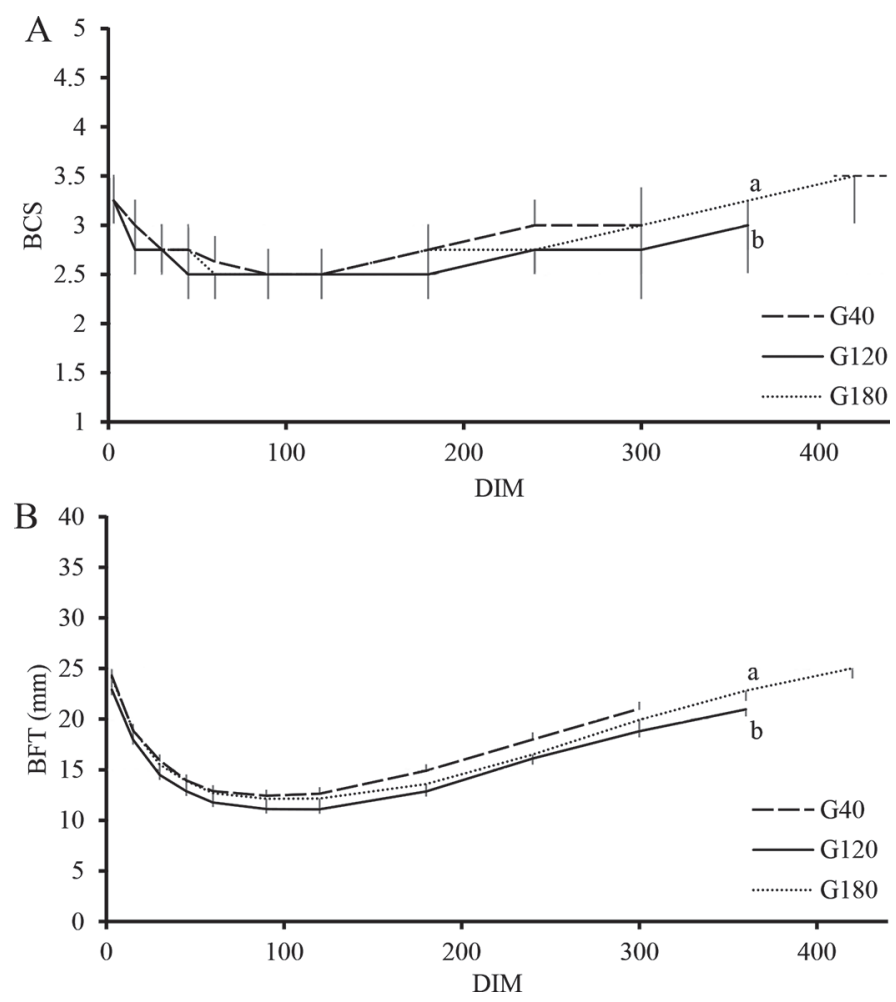

Figure 5. Development of (A) BCS (median \pm median absolute deviation) and (B) back fat thickness (BFT; means \pm SEM) in cows with a 40-, 120-, and 180-d voluntary waiting period (VWP) length (G40, G120, and G180, respectively). Values within a specific time point with different letters $(\mathrm{a}, \mathrm{b})$ differ $(P<0.05)$. system (Kamphuis et al., 2010) and the high number of false-positive mastitis detection alerts in AMS (Steeneveld et al., 2010), the number of animals diagnosed and treated for subclinical mastitis was probably overestimated in our study; however, this was expected to have an equal distribution across groups.

\section{BCS, BFT, and Dry Off Management}

Genetic selection toward milk production in the dairy industry has led to several changes in cattle physiology, such as increased fat tissue mobilization after calving to meet the energetic needs of lactation (Chagas et al., 2009; Lucy et al., 2009). After parturition, the activation of homeorhetic and homeostatic mechanisms lead to the uncoupling of the somatotropic axis (Bauman and Currie, 1980; Bauman, 2000; Roche, 2007), which is characterized by decreased levels of IGF-I and an increase in circulating growth hormone and peripheral insulin resistance, ultimately leading to an enhancement of glycogenolysis and lipolysis (Lucy et al., 2001; Lucy, 2004). These hormonal changes ultimately lead to the early postpartum body fat mobilization and the repartitioning of available nutrients away from body tissue reserves and toward the udder in favor of milk production. As lactation progresses, the recoupling of somatotropic axis shifts the energy partitioning from milk production to body adipose tissue (i.e., decreased lipolysis, increased gluconeogenesis, and lipogenesis; Bauman, 2000). The most used methods to assess the available body nutrient reserves in cows are BCS and BFT (Schröder and Staufenbiel, 2006; Roche et al., 2009). In our study, cows with the longest VWP (i.e., G180) entered the dry off period (or completed their lactation) with greater BCS and BFT values in comparison to cows with short and intermediate length of VWP (i.e., G40 and G120). This finding is in accordance with other studies who found that cows undergoing extended lactations gained more BCS than cows with the typical 10-mo lactating period (Kolver et al., 2006; Auldist et al., 2007). Those previous studies suggested that this finding could be the result of cows spending more time during their extended lactation period under positive energy balance. Animals from G180 had a BCS at dry off greater than 3.5, which could negatively affect dry period management and subsequent lactation. High BCS at dry off and calving has been associated with disease and productivity loss in the early puerperium (Pryce and Harris, 2006; Roche et al., 2009). Moreover, cows from the same group had longer dry periods, and therefore more nonlactating days than animals from the remaining groups, although the value of this parameter was still within acceptable limits $(58 \mathrm{~d})$. Irrespective of the groups, parity had an interaction with 
BCS and BFT development throughout the lactation. More specifically, pluriparous cows underwent a greater loss of BCS and BFT during early and mid lactation and entered the dry period with higher values than primiparous cows. This fact can be attributed to the increased persistency of primiparous cows, which makes them more suitable candidates for extended lactation systems (Arbel et al., 2001).

The higher persistency of G120 compared with G40 cows resulted in identical values of these groups regarding dry off duration, milk yield at dry off, and proportion of cows dried off below $15 \mathrm{~kg} / \mathrm{d}$. Only by extending the VWP for a very long period can we succeed to dry-off cows with lower production levels, which could be theoretically advantageous for udder health. However, a drawback could be the milking of cows at levels that are not profitable (Marett et al., 2015), which can result in longer dry periods (Österman and Bertilsson, 2003; Lehmann et al., 2016) and higher culling rates due to low productivity, as noted in our study. Primiparous cows reached dry off at higher production levels compared with pluriparous cows, indicative of the greater persistency.

\section{CONCLUSIONS}

Taking into account the results of the companion and the present study, we concluded that pluriparous cows with lower-than-average milk production are the worst candidates for extended lactation, as they show adequate reproductive efficiency early in lactation and show decreased persistency during lactation. High-yielders are expected to benefit more regarding reproductive performance if the lactation is extended and primiparous cows can sustain a satisfactory level of production for longer periods. Regarding the time period for which the VWP can be extended, based on our results $120 \mathrm{~d}$ is a very promising length, as the animals assigned to this protocol had increased reproductive efficiency, equal daily milk production (compared with a short lactation group), and exhibited no adverse effects on udder health or BCS gain. However, the critical question is how profitable can such an intervention be, which will be addressed with further research.

\section{ACKNOWLEDGMENTS}

The authors express their appreciation to Peter Baling, president of the managing board of the Agrargesellschaft Ruppendorf AG in Klingenberg, Germany, who endorsed the project actively and strongly and was ready to help whenever necessary. We thank the farm crew, in particular Tobias Wagner and Anne Bormann (Agrargesellschaft Ruppendorf AG, Klingenberg, Ger- many), for their indispensable provision of assistance during the study. We also thank the reviewers for the very constructive comments.

\section{REFERENCES}

Arbel, R., Y. Bigun, E. Ezra, H. Sturman, and D. Hojman. 2001. The effect of extended calving intervals in high-yielding lactating cows on milk production and profitability. J. Dairy Sci. 84:600-608. https://doi.org/10.3168/jds.S0022-0302(01)74513-4.

Auldist, M. J., C. Grainger, A. V. Houlihan, J. J. Mayes, and R. P. Williams. 2010. Composition, coagulation properties, and cheesemaking potential of milk from cows undergoing extended lactations in a pasture-based dairying system. J. Dairy Sci. 93:14011411. https://doi.org/10.3168/jds.2009-2727.

Auldist, M. J., G. O'Brien, D. Cole, K. L. Macmillan, and C. Grainger. 2007. Effects of varying lactation length on milk production capacity of cows in pasture-based dairying systems. J. Dairy Sci. 90:3234-3241. https://doi.org/10.3168/jds.2006-683.

Bauman, D. E. 2000. Regulation of nutrient partitioning during lactation: Homeostasis and homeorhesis revisited. Pages 311-328 in Ruminant Physiology: Digestion, Metabolism, Growth and Reproduction. P. B. Cronji, ed. CABI Publishing, Oxon, UK.

Bauman, D. E., and W. B. Currie. 1980. Partitioning of nutrients during pregnancy and lactation: a review of mechanisms involving homeostasis and homeorhesis. J. Dairy Sci. 63:1514-1529. https:// doi.org/10.3168/jds.S0022-0302(80)83111-0.

Borman, J. M., K. L. Macmillan, and J. Fahey. 2004. The potential for extended lactations in Victorian dairying: A review. Aust. J. Exp. Agric. 44:507-519. https://doi.org/10.1071/EA02217.

Butler, S. T., L. Shalloo, and J. J. Murphy. 2006. An evaluation of extended lactation as a strategy to alleviate reproductive loss in a seasonal pasture-based system. J. Dairy. Sci. 89(Suppl. 1):195. (Abstr.)

Chagas, L. M., M. C. Lucy, P. J. Back, D. Blache, J. M. Lee, P. J. Gore, A. J. Sheahan, and J. R. Roche. 2009. Insulin resistance in divergent strains of Holstein-Friesian dairy cows offered fresh pasture and increasing amounts of concentrate in early lactation. J. Dairy Sci. 92:216-222. https://doi.org/10.3168/jds.2008-1329.

Delany, K. K., K. L. Macmillan, C. Grainger, P. C. Thomson, D. Blache, K. R. Nicholas, and M. J. Auldist. 2010. Blood plasma concentrations of metabolic hormones and glucose during extended lactation in grazing cows or cows fed a total mixed ration. J. Dairy Sci. 93:5913-5920. https://doi.org/10.3168/jds.2010-3609.

Edmonson, A. J., I. J. Lean, L. D. Weaver, T. Farver, and G. Webster. 1989. A body condition scoring chart for Holstein dairy cows. J. Dairy Sci. 72:68-78. https://doi.org/10.3168/jds.S0022 -0302(89)79081-0.

GfE. 2001. Empfehlungen für Energie und Nährstoffversorgung der Milchkühe und Aufzuchtrinder. DLG, Verlag, Frankfurt/Main, Germany.

Hagnestam-Nielsen, C., U. Emanuelson, B. Berglund, and E. Strandberg. 2009. Relationship between somatic cell count and milk yield in different stages of lactation. J. Dairy Sci. 92:3124-3133. https:/ /doi.org/10.3168/jds.2008-1719.

Hortet, P., F. Beaudeau, H. Seegers, and C. Fourichon. 1999. Reduction in milk yield associated with somatic cell counts up to 600000 cells/ml in French Holstein cows without clinical mastitis. Livest. Prod. Sci. 61:33-42. https://doi.org/10.1016/s0301-6226(99)00051 -2 .

Kamphuis, C., H. Mollenhorst, J. A. P. Heesterbeek, and H. Hogeveen. 2010. Detection of clinical mastitis with sensor data from automatic milking systems is improved by using decision-tree induction. J. Dairy Sci. 93:3616-3627. https://doi.org/10.3168/jds.2010-3228.

Knight, C. H. 2005. Extended lactation: Turning theory into reality. Adv. Dairy Technol. 17:113-124.

Kolver, E. S., J. R. Roche, C. R. Burke, and P. W. Aspin. 2006. Effect of genotype and diet on milksolids production, body condition, and reproduction of cows milked continuously for 600 days. Pages 245-251 in Proceedings of the New Zealand Society of Animal 
Production. Vol. 66. New Zealand Society of Animal Production, Napier, New Zealand.

Kolver, E. S., J. R. Roche, C. R. Burke, J. K. Kay, and P. W. Aspin. 2007. Extending lactation in pasture-based dairy cows: I. Genotype and diet effect on milk and reproduction. J. Dairy Sci. 90:5518-5530. https://doi.org/10.3168/jds.2007-0324.

Laevens, H., H. Deluyker, Y. H. Schukken, L. De Meulemeester, R. Vandermeersch, E. De Muelenaere, and A. De Kruif. 1997. Influence of parity and stage of lactation on the somatic cell count in bacteriologically negative dairy cows. J. Dairy Sci. 80:3219-3226. https://doi.org/10.3168/jds.S0022-0302(97)76295-7.

Lehmann, J. O., J. G. Fadel, L. Mogensen, T. Kristensen, C. Gaillard, and E. Kebreab. 2016. Effect of calving interval and parity on milk yield per feeding day in Danish commercial dairy herds. J. Dairy Sci. 99:621-633. https://doi.org/10.3168/jds.2015-9583.

Lucy, M. C. 2004. Mechanisms linking the somatotropic axis with insulin: Lessons from the postpartum dairy cow. Pages 19-23 in Proceedings of the New Zealand Society of Animal Production. Vol. 64. New Zealand Society of Animal Production, Hamilton, New Zealand.

Lucy, M. C., H. Jiang, and Y. Kobayashi. 2001. Changes in the somatotrophic axis associated with the initiation of lactation. J. Dairy Sci. 84:E113-E119. https://doi.org/10.3168/jds.S0022 -0302(01)70205-6.

Lucy, M. C., G. A. Verkerk, B. E. Whyte, K. A. Macdonald, L. Burton, R. T. Cursons, J. R. Roche, and C. W. Holmes. 2009. Somatotropic axis components and nutrient partitioning in genetically diverse dairy cows managed under different feed allowances in a pasture system. J. Dairy Sci. 92:526-539. https://doi.org/10.3168/ jds.2008-1421.

Maciel, G. M., N. A. Poulsen, M. K. Larsen, U. Kidmose, C. Gaillard, J. Sehested, and L. B. Larsen. 2016. Good sensory quality and cheesemaking properties in milk from Holstein cows managed for an 18-month calving interval. J. Dairy Sci. 99:8524-8536. https:// doi.org/10.3168/jds.2016-10958.

Marett, L. C., M. J. Auldist, C. Grainger, W. J. Wales, D. Blache, K. L. Macmillan, and B. J. Leury. 2011. Temporal changes in plasma concentrations of hormones and metabolites in pasture-fed dairy cows during extended lactation. J. Dairy Sci. 94:5017-5026. https: //doi.org/10.3168/jds.2011-4272.

Marett, L. C., M. J. Auldist, P. J. Moate, W. J. Wales, K. L. Macmillan, F. R. Dunshea, and B. J. Leury. 2015. Response of plasma glucose, insulin, and nonesterified fatty acids to intravenous glucose tolerance tests in dairy cows during a 670-day lactation. J. Dairy Sci. 98:179-189. https://doi.org/10.3168/jds.2014-8205.

Marett, L. C., M. J. Auldist, W. J. Wales, K. L. Macmillan, F. R. Dunshea, and B. J. Leury. 2017. Responses of plasma glucose and nonesterified fatty acids to intravenous insulin tolerance tests in dairy cows during a 670-day lactation. J. Dairy Sci. 100:32723281. https://doi.org/10.3168/jds.2016-11985.

Niozas, G., G. Tsousis, I. Steinhöfel, C. Brozos, A. Römer, S. Wiedemann, H. Bollwein, and M. Kaske. 2019. Extended lactation in high-yielding dairy cows. I. Effects on fertility measurements. J. Dairy Sci. 102:799-810. https://doi.org/10.3168/jds.2018-15115.

Österman, S., and J. Bertilsson. 2003. Extended calving interval in combination with milking two or three times per day: Effects on milk production and milk composition. Livest. Prod. Sci. 82:139 149. https://doi.org/10.1016/S0301-6226(03)00036-8.

Österman, S., K. Östensson, K. Svennersten-Sjaunja, and J. Bertilsson. 2005. How does extended lactation in combination with different milking frequencies affect somatic cell counts in dairy cows? Livest. Prod. Sci. 96:225-232. https://doi.org/10.1016/j.livprodsci .2005.01.014.

Penasa, M., M. De Marchi, and M. Cassandro. 2016. Short communication: Effects of pregnancy on milk yield, composition traits, and coagulation properties of Holstein cows. J. Dairy Sci. 99:48644869. https://doi.org/10.3168/jds.2015-10168.
Pryce, J. E., and B. L. Harris. 2006. Genetics of body condition score in New Zealand dairy cows. J. Dairy Sci. 89:4424-4432. https:// doi.org/10.3168/jds.S0022-0302(06)72490-0.

Rajala-Schultz, P. J., J. S. Hogan, and K. L. Smith. 2005. Short communication: Association between milk yield at dry-off and probability of intramammary infections at calving. J. Dairy Sci. 88:577-579. https://doi.org/10.3168/jds.S0022-0302(05)72720-X.

Roche, J. R. 2007. Milk production responses to pre- and postcalving dry matter intake in grazing dairy cows. Livest. Sci. 110:12-24. https://doi.org/10.1016/j.livsci.2006.08.016.

Roche, J. R., N. C. Friggens, J. K. Kay, M. W. Fisher, K. J. Stafford, and D. P. Berry. 2009. Invited review: Body condition score and its association with dairy cow productivity, health, and welfare. J. Dairy Sci. 92:5769-5801. https://doi.org/10.3168/jds.2009-2431.

Roemer, A. 2011. Investigations on longevity in German Holstein cows. Zuchtungskunde 83:8-20.

Schröder, U. J., and R. Staufenbiel. 2006. Invited review: Methods to determine body fat reserves in the dairy cow with special regard to ultrasonographic measurement of backfat thickness. J. Dairy Sci. 89:1-14. https://doi.org/10.3168/jds.S0022-0302(06)72064-1.

Schukken, Y. H., G. J. Bennett, M. J. Zurakowski, H. L. Sharkey, B. J. Rauch, M. J. Thomas, B. Ceglowski, R. L. Saltman, N. Belomestnykh, and R. N. Zadoks. 2011. Randomized clinical trial to evaluate the efficacy of a 5-day ceftiofur hydrochloride intramammary treatment on nonsevere gram-negative clinical mastitis. J. Dairy Sci. 94:6203-6215. https://doi.org/10.3168/jds.2011-4290.

Sharma, N., T. Y. Kang, S. J. Lee, J. N. Kim, C. H. Hur, J. C. Ha V. Vohra, and D. K. Jeong. 2013. Status of bovine mastitis and associated risk factors in subtropical Jeju Island, South Korea. Trop. Anim. Health Prod. 45:1829-1832. https://doi.org/10.1007/ s11250-013-0422-3.

Sheldon, I. M., G. S. Lewis, S. LeBlanc, and R. O. Gilbert. 2006. Defining postpartum uterine disease in cattle. Theriogenology 65:1516-1530. https://doi.org/10.1016/j.theriogenology.2005.08 .021 .

Silvestre, A. M., F. Petim-Batista, and J. Colaço. 2006. The accuracy of seven mathematical functions in modeling dairy cattle lactation curves based on test-day records from varying sample schemes. J. Dairy Sci. 89:1813-1821. https://doi.org/10.3168/jds.S0022 -0302(06)72250-0.

Sorensen, A., D. D. Muir, and C. H. Knight. 2008. Extended lactation in dairy cows: Effects of milking frequency, calving season and nutrition on lactation persistency and milk quality. J. Dairy Res. 75:90-97. https://doi.org/10.1017/S0022029907002944.

Spiegelhalter, D. J., A. Thomas, and N. Best. 2004. WinBUGS Version 1.4.1. MRC Biostatistics Unit, Cambridge, UK.

Steeneveld, W., L. C. van der Gaag, W. Ouweltjes, H. Mollenhorst, and H. Hogeveen. 2010. Discriminating between true-positive and false-positive clinical mastitis alerts from automatic milking systems. J. Dairy Sci. 93:2559-2568. https://doi.org/10.3168/jds .2009-3020.

van Amburgh, M. E., D. M. Galton, D. E. Bauman, and R. W. Everett. 1997. Management and economics of extended calving intervals with use of bovine somatotropin. Livest. Prod. Sci. 50:15-28. https://doi.org/10.1016/s0301-6226(97)00069-9.

Vargas, B., W. J. Koops, M. Herrero, and J. A. M. van Arendonk. 2000. Modeling extended lactations of dairy cows. J. Dairy Sci. 83:1371-1380. https://doi.org/10.3168/jds.S0022-0302(00)75005 $-3$.

Weller, J. I., and Y. Folman. 1990. Effects of calf value and reproductive management on optimum days to first breeding. J. Dairy Sci. 73:1318-1326. https://doi.org/10.3168/jds.S0022-0302(90)78798 $-\mathrm{X}$.

Wilmink, J. B. M. 1987. Adjustment of test-day milk, fat and protein yield for age, season and stage of lactation. Livest. Prod. Sci. 16:335-348. https://doi.org/10.1016/0301-6226(87)90003-0. 